原著胃液分泌に及ぼす鍼炎刺激の影響

池内 隆治* 長谷川 汪田和 宗徳

要旨：東洋医学において古くから消化器疾患に対して種々の経穴が用いられ銊 炎治療が行われている。胃疾患に対しては足三里，陽陵泉などの経穴がよく用 いられているが, 足三里では胃酸の分泌が立進する傾向があり，胃酸過多の者 には用いず陽陵泉を用いる方がよいといい伝えられている。これら経穴の特性 についてはいかなる病態生理に基づいたものであるか不明である。

今回，われわれは，テレメトリ胃腸内 $\mathrm{pH}$ 值測定機を用いて，それぞれの経穴 と胃疾患と関係の深い胃液 $\mathrm{pH}$ 值の変動について検討を加えた結果, 足三里刺激 群, 梁丘刺激群は胃液の塩酸分泌を光進する傾向がみられ, 陽陵泉刺激群は胃 液の塩酸分泌を抑制する傾向がみられた。

\section{I. 緒言}

現代社会において消化器疾患は，社会情勢の複 雑化に伴い増加の途をたどっており，特に胃・十 二指腸潰痬はその傾向が著しい。これらの疾患の 治療に関しては，現在では生化学的あるいは組織 化学的な技術の進歩により消化管ホルモンや組織 $\mathrm{pH}$ 值の測定 ${ }^{1)}$ な゙が可能となり，疾患の病態生理 が解明され，これに基づいた治療法が行われてい る。

一方，東洋医学においても古くから消化器疾患 に対して種々の経穴を用い鍼炎治療が行われてき ており，それぞれの効果が認められている。胃疾 患に対しては中脘, 梁門, 足三里, 陽陵泉などの 経穴 ${ }^{2,3}$ がよく用いられている。このうち足三里につ いては古くから過酸の者には用いない方が望まし く，むしろ陽陵泉を用いる方がよいといい伝えら れている。しかしこれがいかなる病態生理に基づ

※ Takaharu Ikeuchi. 明治鐵炎短期大学助手 (東洋医学教 室)

共同研究者：Hiroshi Hasegawa, M.D. 明治銊炎短期大学 教授 (臨床医学教室) Munenori Tawa 明治銊尒短期大学 (専攻科)

Key Words : テレメトリ胃腸内 $\mathrm{pH}$ 值測定, 足三里, 陽陵 泉, 塩酸分泌, 鐵刺激
いたものかは不明である。したがって、われわれ は胃疾患と関係の深い胃液の性状, 特にその $\mathrm{pH}$ 值 の変動すなわち塩酸分泌と胃疾患の経穴としてよ く用いられる足三里および陽陵泉との関係につい て検討を行い，2、3 の知見を得たので報告する。

\section{II. 実験方法}

対象は胃疾患の現病歴および既往歴のない 18 22歳の本学学生 8 名（男 7 名, 女 1 名) を選 び，実験前日の夜から実験開始までに 12 時間以上 の絶飲食を行った後, 実験に臨んだ。

胃内 $\mathrm{pH}$ 值測定には八イデルベルグ社製テレメト リ一胃腸内 $\mathrm{pH}$ 值測定装置 ${ }^{4 \sim 6)}$ を用いた。

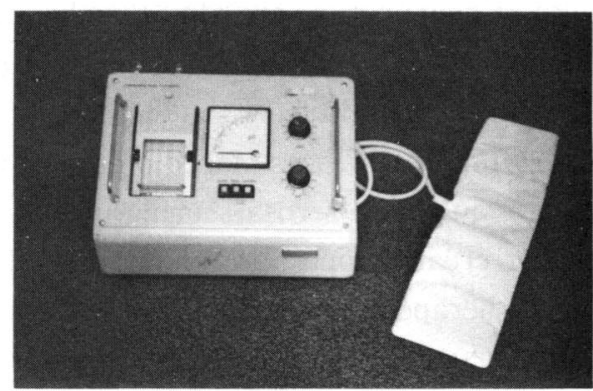

写真 1 : テレメトリ胃腸内 $\mathrm{pH}$ 値測定器

(左は本体, 右はバンドアンテナ).

本機械は測定值変換器, 送信器および高周波発 信器が組み込まれた抗生物質大 (直径 $8 \mathrm{~mm}$, 長さ 
$20 \mathrm{~mm}$, 重さ $1.5 \mathrm{~g})$ のラジオカプセルを胃の中に飲 み込み胃内の $\mathrm{pH}$ 值を感知し，それを信号に变換， 送信し，体外に置いたバンドアンテナおよび較正 アンテナで電波をキャッチし受信機に導き増幅さ れ表示, 自動記録していくものである(写真1，2）。

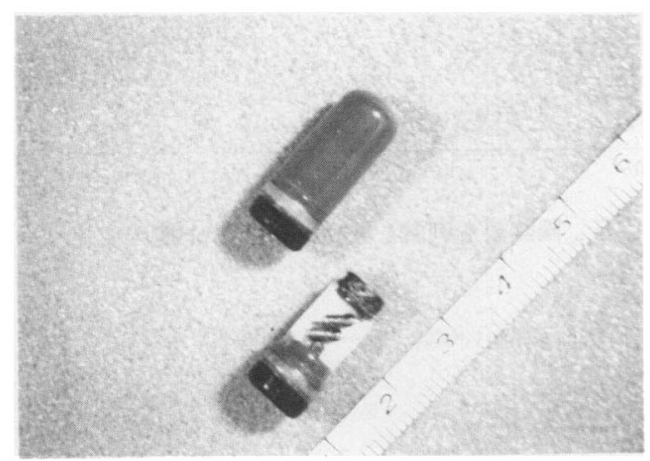

写真 2. テレメトリ胃腸内pH値測定用カプセル

このラジオカプセルは胃の蝡動運動により腸内 へ移行するため胃内の $\mathrm{pH}$ の変動を経時的に測定す るためには胃内に止めておく必要がある。このた めラジオカプセルに糸をつけ, 閒歯より $45 \mathrm{~cm}$ 前後 のところで $\mathrm{pH}$ 值が強酸性を示すことによりカプセ ルが胃に存在することを確認した後，その系を固 定した。

胃液の塩酸分泌の状態を観察するには強酸性で ある胃液を一度中性化した後，塩酸分泌により胃 液の $\mathrm{pH}$ が酸性化していく, すなわち基礎 $\mathrm{pH}$ に復 帰するまでの経過を観察する必要がある。したが って, 今回, 胃液中性化の目的で $\mathrm{MgCO}_{3} 6 \%$ の懸 濁液を $10 \mathrm{ml}$, 経口服用させた。これによって胃内 $\mathrm{pH}$ 值は5.5〜 7.5に変化し，この $\mathrm{pH}$ 值が基礎 $\mathrm{pH}$ 值（1.0 2.0）に復するまでの時間およびそのパ ターンについて観察を行った。

鍼刺激法としては，両側の足三里，梁丘，陽陵 泉, 外丘を選び, ステンレス製, 1 寸 6 分, 5 番 銊を用い, それぞれ $2.5 \mathrm{~cm} \sim 3.0 \mathrm{~cm}$ 刺入し, 低周 波装置によって $3 \mathrm{~Hz}, 15$ 分間の低周波置鍼刺激を 行った。

対照群としては $\mathrm{MgCO}_{3}$ にっって胃液を中性化し, 鍼刺激を加えず, 基礎 $\mathrm{pH}$ に復するまで観察を行っ た。

\section{III. 実験成績}

1. $\mathrm{MgCO}_{3}$ による胃液中性後, 塩酸分泌により基 礎 $\mathrm{pH}$ 值に復帰するまでの時間について検討を行っ た（図 1 ，表1）。

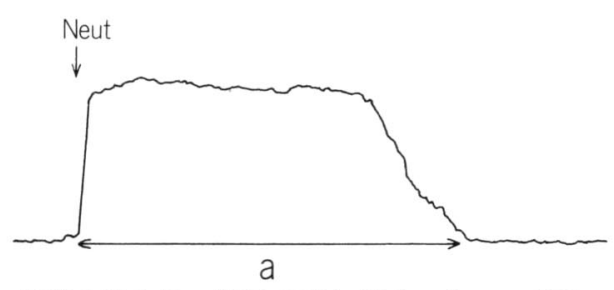

図 1 . 胃液中性化後, 基礎 $\mathrm{pH}$ 値に復するまでの時間( $\mathrm{a}$ )

表 1 . 胃液中性化後, 基礎 $\mathrm{pH}$ 值に復帰するまでの時間 ( $\mathrm{a}$ )

\begin{tabular}{|c|c|c|}
\hline \multicolumn{2}{|c|}{ 刺 激 部 位 } & Mean $\pm \mathrm{SE}(\min )$ \\
\hline 対 & 照 & $18.9 \pm 2.5$ \\
\hline 足 三 & 里 & $14.6 \pm 1.5$ \\
\hline 梁 & 丘 & $14.1 \pm 1.5$ \\
\hline 陽 陵 & 泉 & $21.6 \pm 2.0$ \\
\hline 外 & 兵 & $18.2 \pm 2.3$ \\
\hline
\end{tabular}

対照群では, $18.9 \pm 2.5$ 分 $($ Mean $\pm \mathrm{SE})$ であっ た。

足三里刺激群では14.6+1.5分 (Mean $\pm \mathrm{SE})$ を 示し, 対照群に比較し約 $22.8 \%$ の短縮がみられた。

梁丘刺激群では $14.1 \pm 1.5$ 分 (Mean $\pm \mathrm{SE})$ とな ク，対照群に比較し $25.8 \%$ の短縮を認めた。

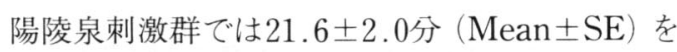
示し,対照群に比較し $14.0 \%$ の延長が認められた.

外丘刺激群では, 18.2 2 2.3分 (Mean $\pm \mathrm{SE})$ を 示し, 対照群とほぼ同様の值を示した。

2. 中性化後，塩酸分泌により酸性化していく経 過を観察した（図2,3,4,5,6)。

足三里刺激群および梁丘刺激群では, 中性を保 つている時間が短縮する傾向が認められ，その後 塩酸分泌による酸性化において対照群に比へてて急 峻な勾配を示した（网2,3,4)。

陽陵泉刺激群では中性の保持時間が延長する傾 向にあり，その後塩酸分泌による酸性化において 
は対照群に比べてその勾配は緩やかになっている (図2,5)。

外丘刺激群では中性保持時間も, 酸性化におけ る勾配も対照群とほぼ同様の傾向を認めた（図2, $6)$ 。

\section{IV. 考察}

ラジオカプセルは本来胃内の $\mathrm{pH}$ 值を測定するも のであり，胃内の酸の濃度を示すものである。今 回，われわれはこのラジオカプセルを用いて胃酸

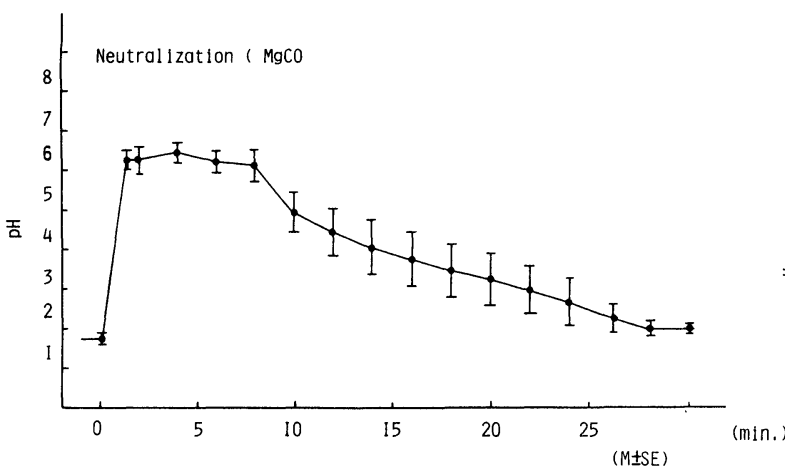

図2，対象群における呩内pH值の变化

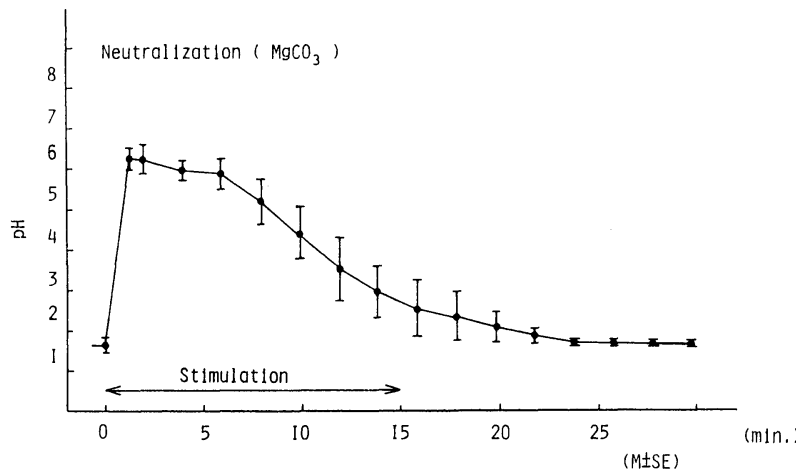

図3，足三里を刺激したときの周内pH值の变化

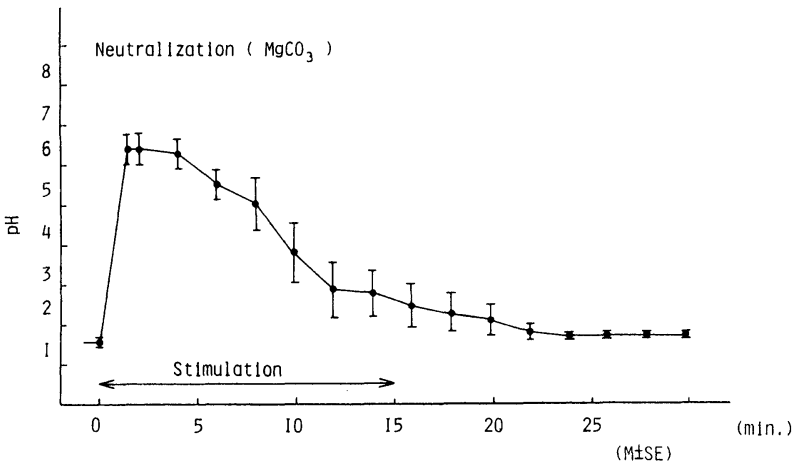

図4．梁丘を刺激したときの骨内pH値の变化

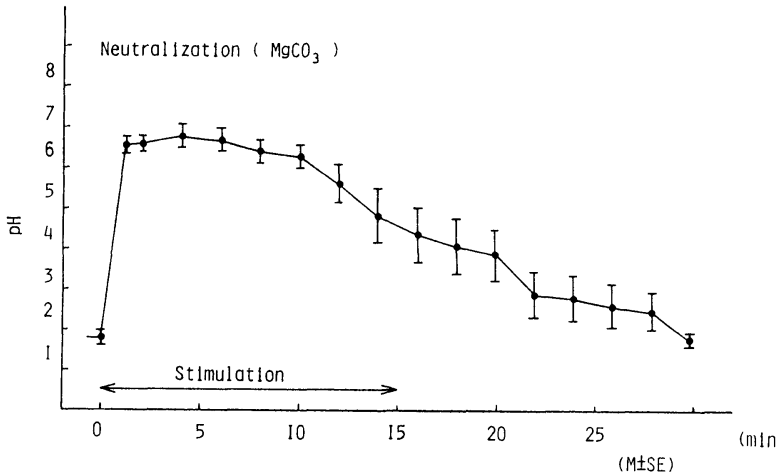

図 5.陽陵泉を刺激したときの男内pH値の変化

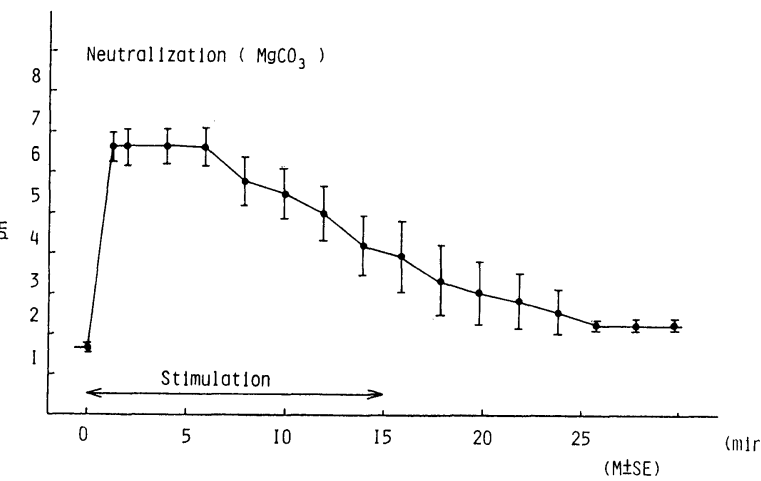

图6 . 外丘を刺激したときの胃内pH値の変化

の分泌状態について観察した。胃は持続的に壁細 胞から塩酸を分泌しているという特徵を捕之てお

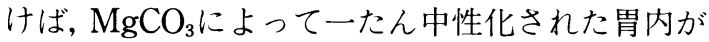
徐々に基礎 $\mathrm{pH}$ 值に復帰する経過は胃酸の分泌状 態を知る指標であると考える。

まず $\mathrm{MgCO}_{3}$ によっていったん中性化された胃液 が基礎 $\mathrm{pH}$ に復帰するまでの時間について検討をす ると, 足三里刺激群, 梁丘刺激群は対照群と比較 してそれぞれ $22.8 \% ， 25.8 \%$ 時間が短縮してい る。基礎 $\mathrm{pH}$ 值に復帰するまでの時間が, 短縮する ということは, 無刺激の場合よりも胃の塩酸分泌 が六進し，すみやかに基礎 $\mathrm{pH}$ 值に復帰したと考之 られる。足三里刺激群については代田文誌らの ${ }^{2,7)}$ 足 三里は胃酸の分泌を充進する傾向にあるという報 告と一致する。陽陵泉刺激群では基礎 $\mathrm{pH}$ 值に復帰 する時間が $14.0 \%$ 延長する傾向が認められた。こ のことは胃の塩酸分泌が抑制されたと考えられる。 次に経時的に胃液 $\mathrm{pH}$ 值の平均值を表すと, 足三 里刺激群，梁丘刺激群では中性を保つ時間が短く (図1,2,3)，陽陵泉刺激群では中性を保つ時間が 
延長している（図2,5）。無刺激の対照群と比較し て中性保持時間が短縮する傾向にあるということ は胃の壁細胞からの塩酸分泌の充進がうかがわれ る。延長の傾向にあるということは塩酸の分泌が 抑制される傾向を示寸ものと考之られる。

また中性を経て基礎 $\mathrm{pH}$ 值に復帰していく曲線の 勾配を比較してみると, 足三里刺激群, 梁丘刺激 群では急峻な勾配を呈して基礎 $\mathrm{pH}$ 值に復帰してい る。陽陵泉刺激群では緩かな勾配を呈して基礎 $\mathrm{pH}$ 值に復帰している。これらの基礎 $\mathrm{pH}$ 值復帰曲線の 勾配の緩急は，中性化後における単位時間あたり の胃の壁細胞からの塩酸の分泌量を表すと考之ら れる。すなわち, 勾配の急な足三里刺激群, 梁丘 刺激群は単位時間における胃の塩酸分泌量が立進 したと考えられ，勾配の緩かな陽陵泉刺激群は単 位時間における胃の塩酸分泌量が抑制されたと考 えられる。

今回の実験では，対象数が少く胃液分泌機能の 個体差が著しいため，統計処理上明らかな有意差 は認められ得なかったが，今後症例数を増して刺 激方法にも検討を加之て胃液分泌機能と銊炎刺激 の関連性を追求する必要があると考える。

\section{V。結 語}

今回の実験では，足三里刺激群および梁丘刺激 群では, $\mathrm{MgCO}_{3}$ による性化後，中性を保持する 時間ならびに基礎 $\mathrm{pH}$ 值に復帰するまでの時間が短 縮し，その曲線は急峻な勾配を示し胃の塩酸分泌 が六進する傾向が認められた。

陽陵泉刺激群では中性を保持する時間と基礎 $\mathrm{pH}$ 值に復帰するまでの時間が延長し, 基礎 $\mathrm{pH}$ 值復帰 曲線は緩かな勾配を示し胃の塩酸分泌の抑制され る傾向が認められた。

外丘刺激群では対照群とほぼ同様の傾向を認め

\section{引用文献}

1）松尾裕・関敦子：消化管分泌における消化管ホル モンと自律神経との協働，日本医師会雑誌。75・ $5: 453-482,1976$.

2）長濱善夫：針炎治療の新研究，創元社，大阪, 1981，149-181. 160.

3）白井彰：鍼尒医学, 白井物理医学研究所, 大阪, 1977, 94-95.

4) Mackay, R.S., Jacobson, B. : The LANCET, A pH-ENDORADIOSONDE, p1224, june, 15, 1957.

5) Hans Günter Nöller: Die Endoradiosonde zur elektrischen pH-Messung im Magen und ihre klinische Bedeutung, Nr. 39, 23. September 1960. p1707-1713.

6) A.M.Connell, T.E. Waters : Assessment of Gastric Function By pH Telemetering Capsule, The LANCET, August 1, 1964, p227-230.

7）代田文誌：銊炎治療の実験（上), 創元社, 大阪, p515, 1966.

8) Joseph. O.A. Sodipo, et,: Acupuncture and Gastric Acid Studies, American Journal of Chinese Medicine, Vol. VII, No. 4, pp.356-361. 1979.

9）川井啓市：胃その形態とその機能，医学書院，東 京, 1975, p69-91.

10）三好秋馬・白鳥常雄：胃分泌の病態と生理，みつ ほ出版，東京，1976，p5-10・p135-142.

11）三澤正ほか：胃液分泌抑制に関する臨床的検討, 臨床と研究. 55・6：p144-147, 1978.

12）真田節・上田一作：酸塩基平衡と $\mathrm{pH} の$ 意味，医 学のあゆみ. $115 ・ 11: \mathrm{p} 864-869$.

（广629-03 京都府船井群日吉町 明治鍼炎短期大 学) た。 


\title{
Effects of Acupuncture on the Secretion of Gastric Juices
}

\author{
Takaharu Ikeuchi \\ Department of Oriental Medicine \\ Hiroshi Hasegawa,M.D. \\ Department of Clinical Medicine \\ Munenori Tawa \\ Postgraduate Course \\ Meiji College of Acupuncture Medicine
}

From ancient times the oriental medicine has applied the acupuncture therapy,choosing various meridian points, to the diseases of the digestive system.

Against the gastric diseases meridian points Tsusanli (S36), Yangling-chuan (G34) etc. are usually used. However, it is traditionally handed down that the puncture to Tsusanli tends to increase gastric secretion,therefore the puncture to Yanglingchuan is better for gastric hyperacidity than that to Tsusanli.

On these meridian points, its pathophysiological mechanism for the diseases of the digestive system of these meridian points still remains unknown.

In these paper, an evaluation on the change of $\mathrm{pH}$ value of gastric juice was carried out by using Telemeter for gastroenteric $\mathrm{pH}$ value, concerning Tsusanli, Yanglingchuan,Liangchiu (S34), and Waichiu (G36).

It was obtained that the tendency to increase the secretion of $\mathrm{HCI}$ in gastric juice in the group stimulated to Tsusanli and the group to Lingchiu, and the tendency to inhibit the secretion in the group to Yanglingchuan. 